\title{
Performance of Avocado Seed Activated Carbon as Adsorbent for Highly Sensitive Determination of Cd Using a Flow Injection System Online Coupled to TS-FF-AAS
}

\author{
Marianne V. F. Kudo, ${ }^{a}$ Leandro L. G. de Oliveira, ${ }^{a}$ Fabio A. C. Suquila, ${ }^{a}$ \\ Fernanda G. de Almeida, ${ }^{a}$ Mariana G. Segatelli, ${ }^{a}$ Éder C. Lima, ${ }^{b}$ \\ Silvio L. P. Dias ${ }^{b}$ and César R. T. Tarley ${ }^{\circledR *, a, c}$ \\ ${ }^{a}$ Departamento de Química, Universidade Estadual de Londrina (UEL), \\ 86051-990 Londrina-PR, Brazil \\ ${ }^{b}$ Instituto de Química, Universidade Federal do Rio Grande do Sul (UFRGS), \\ 90040-060 Porto Alegre-RS, Brazil \\ 'Instituto Nacional de Ciência e Tecnologia em Bioanalítica (INCTBio), \\ Departamento de Química Analítica, Instituto de Química, \\ Universidade Estadual de Campinas (Unicamp), 13083-970 Campinas-SP, Brazil
}

\begin{abstract}
A flow-injection preconcentration system using detection by the thermospray flame furnace atomic absorption spectrometry (FIA-TS-FF-AAS) is proposed. $\mathrm{Cd}^{2+}$ are adsorbed on avocado seed activated carbon (ASAC) packed into a cylindrical mini-column and eluted using $\mathrm{HCl}$ solutions for the detection system. A $2^{5-1}$ fractional factorial and Doehlert matrix design were employed to determine the optimum conditions for cadmium preconcentration $(\mathrm{pH} \mathrm{7.68}$, buffer concentration (Tris/Tris-HCl) of $0.023 \mathrm{~mol} \mathrm{~L}^{-1}$, eluent concentration $(\mathrm{HCl})$ of $2.0 \mathrm{~mol} \mathrm{~L}^{-1}$, the adsorbent mass of $100.0 \mathrm{mg}$ and preconcentration flow rate of $\left.4.8 \mathrm{~mL} \mathrm{~min}^{-1}\right)$. The preconcentration method presents linearity within the range of $0.41-15.00 \mu \mathrm{g} \mathrm{L}^{-1}$, limits of quantification and detection of 0.41 and $0.12 \mu \mathrm{g} \mathrm{L} \mathrm{L}^{-1}$, respectively, preconcentration factor of 10.7 , consumption of index of $0.93 \mathrm{~mL}$ and sample throughput of $26 \mathrm{~h}^{-1}$. The precision assessed as the relative standard deviation (RSD) were found to be $0.48,0.90$ and $2.30 \%$ for inter-day precision $(n=2)$, and $0.30,0.44$ and $2.48 \%$ for intra-day precision $(n=6)$ for respective cadmium concentration of $0.50,5.00$ and $15.00 \mu \mathrm{g} \mathrm{L}^{-1}$. The proposed method was applied satisfactorily in samples of cigarette $\left(62.84 \pm 11.28 \mu \mathrm{g} \mathrm{kg}^{-1}\right)$, human hair $\left(69.61 \pm 2.38 \mu \mathrm{g} \mathrm{kg}^{-1}\right)$ and water samples [lake $\left(0.65 \pm 0.01 \mu \mathrm{g} \mathrm{\textrm {L } ^ { - 1 }}\right)$, tap and mineral].
\end{abstract}

Keywords: thermospray flame furnace atomic absorption spectrometry, Doehlert matrix, water samples, cigarette, human hair

\section{Introduction}

Currently, due to various anthropological activities, trace metals are discarded in aquatic environments. They can be absorbed by living organisms and bioaccumulate, distributing themselves through food chain until reaching human organism, becoming harmful to health. ${ }^{1,2}$ Among these metals, cadmium is considered a potentially toxic element (PTE) and classified as a human carcinogen according to the International Agency for Research on Cancer (IARC).$^{3-5}$ For this reason, in order to perform a continuous monitoring, even at trace level, international and national legislation [United States Environmental

*e-mail: ctarleyquim@yahoo.com.br
Protection Agency (USEPA), World Health Organization (WHO), Brazilian Health Regulatory Agency (ANVISA), National Environment Council (CONAMA)] establishes allowed maximum limits of cadmium for different kinds of water. For drinking water were established maximum limits of $5.0 \mu \mathrm{g} \mathrm{L}^{-1}$ by USEPA ${ }^{6}$ and $3.0 \mu \mathrm{g} \mathrm{\textrm {L } ^ { - 1 }}$ by ANVISA and $\mathrm{WHO},{ }^{7,8}$ while for freshwater the established maximum limit by CONAMA ${ }^{9}$ is $10.0 \mu \mathrm{g} \mathrm{L}^{-1}$. In this context, some traditional spectro-analytical techniques, such as inductively coupled plasma optical emission spectrometry (ICP OES), inductively coupled plasma mass spectrometry (ICP-MS), flame atomic absorption spectrometry (FAAS), and electrothermal atomic absorption spectrometry (ETAAS) were employed for the determination of metals ions. Among them, the FAAS technique stands out due 
to its high simplicity of instrumentation and low cost of acquisition and maintenance. ${ }^{10}$ However, its sensitivity is usually insufficient for the determination of metal ions at concentration level below $\mu \mathrm{g} \mathrm{L}{ }^{-1} .{ }^{11}$ In order to improve the sensitivity of FAAS, thermospray flame furnace atomic absorption spectrometry (TS-FF-AAS) has been used as an alternative technique, which makes possible to complete sample introduction into the furnace with longer time of metal residence in the flame, thus improving atomization and, consequently, higher sensitivity. ${ }^{10,12}$ The performance of TS-FF-AAS for trace metal determination has been widely improved when associated with preconcentration methods. ${ }^{13}$ The most common preconcentration methods associated with TS-FF-AAS include dispersive liquidliquid microextraction (DLLME),${ }^{14}$ hollow fiber supported liquid membrane extraction (HF-SLME) ${ }^{15}$ supramolecular solvents based dispersive liquid-liquid microextraction (SUPRAs), ${ }^{16}$ cloud-point extraction (CPE), ${ }^{17,18}$ and solidphase extraction (SPE). ${ }^{19,20}$ Solid-phase extraction has been considered the most common technique because of its advantages as simplicity, automation ease, higher preconcentration factor, reusability of adsorbent and the wide variety of adsorbents that can be employed. It is important to note that the materials used in SPE must be chemically stable, once they must have the capacity to regenerate after the preconcentration/elution step. Different materials can be cited as solid phase adsorbents such as activated carbon (AC) ${ }^{21}$ silica gel, ${ }^{22}$ aluminas, ${ }^{23}$ carbon nanotubes (CNTs), ${ }^{24}$ nickel oxide, ${ }^{25}$ natural polymers ${ }^{26}$ and resins. ${ }^{27}$ Activated carbon (AC) has received considerable interest for the adsorption process in aqueous systems because its textural properties (high specific surface area and pore volume) leads to high adsorption capacity. Besides that AC can be reutilized and they present low cost. ${ }^{28}$ Furthermore, AC can be produced from various agro-industrial products, by-products and waste rich in carbon such as wood, coal, lignite, coconut (endocarp and shell) and seeds (olive, mango, peach, buriti, avocado seed, and others). Thereby materials with different adsorbent properties towards different target analytes can be obtained. AC may be obtained by physical activation process from thermal treatment (pyrolysis) for the removal of volatile components of lower mass (CO, $\mathrm{H}_{2}, \mathrm{CO}_{2}$ and $\mathrm{CH}_{4}$ ), resulting in a material with a structure primary porous, which, subsequently, favors the chemical modification..$^{29}$ One should note that AC obtained without further chemical surface modification has been much more employed for the adsorption of organic compounds and very few exploited for metal ions..$^{30}$ The chemical modification of AC surface has received considerable attention from the researchers, by introducing functional groups $(\mathrm{O}-\mathrm{H}$ from alcohols and phenols and $\mathrm{C}=\mathrm{O}$ from carboxylic acids and esters) which can form metallic complexes. ${ }^{31}$ Therefore, such modification provides to $\mathrm{AC}$ higher adsorption capacity and selectivity towards metal ion when compared with unmodified AC. ${ }^{32}$ Notwithstanding, it must bear in mind that the chemical modification also brings improvements on the surface area of the material. The chemical modification can be performed by the $\mathrm{AC}$ impregnation using $\mathrm{ZnCl}_{2}$, followed by pyrolysis in a conventional furnace or microwave oven. During the pyrolysis process, $\mathrm{Zn}$ forms a complex with the AC, which after its removal with mineral acid $(\mathrm{HCl})$ provides higher porosity and surface area to the adsorbent..$^{33}$ Thereby, chemically modified AC can be an alternative adsorbent in detriment of commerciallyavailable materials currently used for the preconcentration of metallic ions from the aqueous medium. A survey of the literature reveals the use of chemically modified AC from nut shells, ${ }^{34}$ corn $\operatorname{cobs}^{35}$ and coconut shell ${ }^{36}$ for the adsorption of metal ions in the batch system. Nevertheless, the use of chemically modified AC as an adsorbent in SPE for the metal ions online preconcentration using flow injection analysis (FIA) with detection by TS-FF-AAS has not been reported before.

Recently, Leite et al. ${ }^{33}$ chemically modified AC from avocado seed (ASAC) using $\mathrm{ZnCl}_{2}$ as an activating agent for adsorption of resorcinol and 3-aminophenol from simulated effluents. The results showed high adsorption capacity for resorcinol (406.9 $\mathrm{mg} \mathrm{g}^{-1}$ ) and 3-aminophenol $\left(454.5 \mathrm{mg} \mathrm{g}^{-1}\right)$, thereby indicating the high potentiality of such material for metal ion adsorption.

In this context, this paper aimed to develop a reliable and straightforward analytical method using chemically activated carbon with $\mathrm{ZnCl}_{2}$ from ASAC as an adsorbent for $\mathrm{Cd}^{2+}$ in an online preconcentration system coupled to TS-FF-AAS. The feasibility and analytical performance of the method were checked for analysis of real samples such as cigarette, human hair and water samples (lake, tap and mineral).

\section{Experimental}

\section{Chemicals}

All chemicals utilized were of analytical grade. The solutions were prepared using ultrapure water from ELGA PURELAB $^{\circledR}$ Maxima purification system (resistivity of $18.2 \mathrm{M} \Omega \mathrm{cm}$, Lane End, United Kingdom).

The $\mathrm{Cd}^{2+}$ working solution $\left(100 \mu \mathrm{g} \mathrm{L}^{-1}\right)$ was prepared from the stock standard of $1000.0 \mathrm{mg} \mathrm{L}^{-1} \mathrm{of} \mathrm{Cd}^{2+}$, which was obtained by dissolving the cadmium(II) nitrate tetrahydrate 
$\left[\mathrm{Cd}\left(\mathrm{NO}_{3}\right)_{2} \cdot 4 \mathrm{H}_{2} \mathrm{O}, 99.0 \%\right.$, Merck, Rio de Janeiro, $\left.\mathrm{RJ}\right]$ in $5.0 \%(\mathrm{v} / \mathrm{v})$ of nitric acid $\left(\mathrm{HNO}_{3}, \geq 65.0 \%\right.$, Sigma-Aldrich, Steinheim, Germany).

Solutions of $\mathrm{Cu}^{2+}, \mathrm{Pb}^{2+}, \mathrm{Co}^{2+}, \mathrm{Zn}^{2+}, \mathrm{Ca}^{2+}$ and $\mathrm{Fe}^{2+}$ of $1.00 \mathrm{~g} \mathrm{~L}^{-1}$ concentration for interfering ions study were prepared from salts of copper(II) nitrate trihydrate (98.0-103.0\%), lead nitrate (99.0\%), cobalt(II) nitrate hexahydrate (98.0-102.0\%), iron(II) chloride (98.0\%) and zinc nitrate hexahydrate (98.0\%), all procured from Merck (Darmstadt, Germany). Calcium nitrate tetrahydrate $(97.0 \%)$ was obtained from Nuclear (Diadema, SP, Brazil). The lobster hepatopancreas reference material for trace metals (TORT-2, National Research Council of Canada) was used for assessing the accuracy of the analytical method.

Sodium acetate $(99.0 \%)$ and tris(hydroxymethyl) aminomethane hydrochloride $(99.0 \%)$ were procured from Merck (Darmstadt, Germany), and they were used to prepare acetate and Tris buffer, respectively. The $\mathrm{pH}$ of solutions was adjusted by using solutions of $\mathrm{NaOH}$ and $\mathrm{HCl}$.

Nitric acid (65\% weight) and hydrogen peroxide (29.0\% weight) were procured from Synth (Diadema, SP, Brazil). These reactants were utilized for the acid digestion of the samples and the certified reference material (CRM). Acetone ( $\geq 99.0 \%$, Sigma-Aldrich, Steinheim, Germany) was used to degrease the hair samples.

In order to prevent metallic ion contamination, all plastics and glassware were soaked in a $1.4 \mathrm{~mol} \mathrm{~L}^{-1} \mathrm{HNO}_{3}$ solution overnight and then washed excessively with deionized water and dried before its utilization.

The ASAC employed in this study was chemically modified with the activating agent $\mathrm{ZnCl}_{2}$ (impregnation of foreign material) by the microwave-heating process, whose details of synthesis may be found in Leite et al. ${ }^{33}$ The reproducibility of the production of the material is very large. The procedure for microwave assisted pyrolysis of avocado seed ${ }^{33}$ was tested by carrying out various pyrolysis procedures. The obtained material exhibited a high specific surface area $\left(\mathrm{S}_{\mathrm{BET}}\right) 1433 \pm 43 \mathrm{~m}^{2} \mathrm{~g}^{-1}$, and the total pore volume $\left(\mathrm{V}_{\text {tot }}\right)$ was $0.445 \pm 0.013 \mathrm{~cm}^{3} \mathrm{~g}^{-1}$, which corresponds to a variation of $3 \%$ in the surface area and the total pore volume for different pyrolysis obtained. Furthermore, the ASAC particles size chosen was $\leq 106 \mu \mathrm{m}$, which display, in general, irregular shape according to scanning electron microscopy (SEM) images.

\section{Instruments}

Cadmium determination was carried out using a flame atomic absorption spectrometer AA-7000 Shimadzu $^{\circledR}$ (Tokyo, Japan) following the manufacturer recommendations. The thermospray device was assembled utilizing a tube furnace (Inconel ${ }^{\oplus}$ 600, composition: $72.0 \%$ of $\mathrm{Ni}, 14.0-17.0 \%$ of $\mathrm{Cr}, 6.0-10.0 \%$ of $\mathrm{Fe}, 0.15 \%$ of C, $1.0 \%$ of $\mathrm{Mn}$ and $0.5 \%$ of $\mathrm{Si}$, Camacan, Brazil) of $10.0 \mathrm{~cm}$ length and $1.0 \mathrm{~cm}$ inner diameter (i.d.), which is positioned on the burner head by means of a home-made holder, leaving the beam from the lamp to pass through its interior. Six holes of $2.0 \mathrm{~mm}$ i.d. were drilled in the bottom part of the tube for flame penetration. Another hole $(2.0 \mathrm{~mm}$ i.d.) was drilled perpendicular to the bottom holes for insertion of the capillary. This capillary (100 mm of length, $0.5 \mathrm{~mm}$ i.d. and $2.0 \mathrm{~mm}$ outer diameter) made of non-porous ceramic $\left(\mathrm{Al}_{2} \mathrm{O}_{3}, 99.7 \%\right)$ (Friatec, Mannheim, Germany) was used to introduce the solutions and samples inside the tube furnace. The capillary tip, responsible for generating the thermal spray, was about $2.0 \mathrm{~mm}$ inside the tube furnace. Pumping of solutions, samples, and the eluent was performed using a flow-injection system, which was set up by a Gilson peristaltic pump (Villiers, France), pumping tubes, and a homemade commutator injector. All connecting tubes were made of polyethylene of $0.8 \mathrm{~mm}$ i.d.

The $\mathrm{pH}$ of solutions was measured with a Metrohm pHmeter. For acid digestion of the samples and reference material, it was used a Milestone $\operatorname{Inc}^{\circledR}$ Ethos One High Performance (Sorisole, Italy). A Quimis ${ }^{\circledR}$ ultrasonic bath (Diadema, SP, Brazil) was used in sample preparation.

Online preconcentration using FIA-TS-FF-AAS system and method optimization

The schematic online preconcentration using FIA-TSFF-AAS system is depicted in Figure 1.

(a)

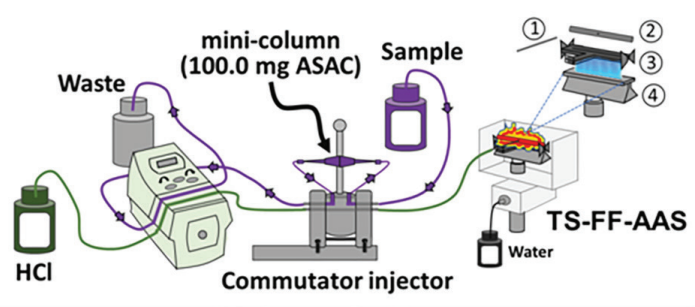

(b)

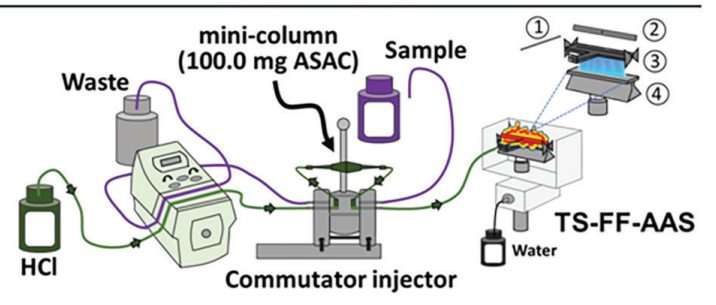

(1) Ceramic capillary (2)Pure nickel tube (3) Home-made holder (4) Standard burner head

Figure 1. Schematic diagram of the FIA-TS-FF-AAS system for preconcentration (a), elution (b) and online $\mathrm{Cd}^{2+}$ determination. ASAC mass: $100.0 \mathrm{mg}, \mathrm{Cd}^{2+}$ standard solution: $10.0 \mu \mathrm{g} \mathrm{L}^{-1}$ at $\mathrm{pH} 7.68$ buffered with Tris/Tris- $\mathrm{HCl}$ buffer $\left(0.023 \mathrm{~mol} \mathrm{~L}^{-1}\right)$, preconcentration volume: $10.0 \mathrm{~mL}$, preconcentration flow rate: $4.8 \mathrm{~mL} \mathrm{~min}^{-1}$, eluent: $\mathrm{HCl}\left(2.0 \mathrm{~mol} \mathrm{~L}^{-1}\right)$ at $0.5 \mathrm{~mL} \mathrm{~min}^{-1}$ flow rate. 
The mini-column was made with pipette tips $(30.0 \mathrm{~mm}$ of length and $7.0 \mathrm{~mm}$ i.d.), where pieces of cotton tissue were used to seal each extremity, avoiding any removal of material absorbent during the preconcentration and elution step. The preconcentration step (Figure 1a) was performed percolating through the mini-column aliquots of $10.0 \mathrm{~mL}$ of sample or $\mathrm{Cd}^{2+}$ standard solution $\left(10.0 \mu \mathrm{g} \mathrm{L}^{-1}\right)$ at $\mathrm{pH} 7.68$ buffered with Tris/Tris-HCl buffer $\left(0.023 \mathrm{~mol} \mathrm{~L}^{-1}\right)$ at $4.8 \mathrm{~mL} \mathrm{~min}^{-1}$ flow rate. Then, the injector was switched (Figure 1b) and a solution of $2.0 \mathrm{~mol} \mathrm{~L}^{-1}$ of $\mathrm{HCl}$ at $0.5 \mathrm{~mL} \mathrm{~min}{ }^{-1}$ flow rate was used to elute the $\mathrm{Cd}^{2+}$ from ASAC adsorbent towards the furnace tube for detection by TS-FF-AAS. The elution step was carried out in a countercurrent of preconcentration step. All experiments were performed thrice $(n=3)$, and the blanks were also performed.

The influence of factors including sample $\mathrm{pH}$, buffer (BC) and eluent (EC) concentration, adsorbent mass (AM) and preconcentration flow rate (PFR), ${ }^{37}$ on the online $\mathrm{Cd}^{2+}$ preconcentration/elution in FIA-TS-FF-AAS system were evaluated by a $2^{5-1}$ fractional factorial design (16 experiments in duplicate), using $10.0 \mathrm{~mL}$ of $\mathrm{Cd}^{2+}$ standard solution, and considering the response as the efficiency of sensibility (ES $=$ absorbance/preconcentration time). Acetate/acetic acid and Tris/Tris- $\mathrm{HCl}$ buffers were used to buffer the solutions at $\mathrm{pH} 5.00$ and 8.00 , respectively.

After establishing the significance of each main factor by the analysis of variance (ANOVA) at $95.0 \%$ confidence interval, a Doehlert matrix (two levels) was employed to determine the optimal conditions for the factors $\mathrm{pH}$ value and buffer concentration (BC). The experimental data were processed by using StatSoft STATISTICA 7.0 software package. ${ }^{38}$

\section{Analytical performance of method}

After obtaining the optimized conditions, the performance of the proposed method was evaluated by the linearity, preconcentration factor $(\mathrm{PF})$, concentration efficiency (CE), consumption of index (CI), sample throughput (ST), limit of detection (LOD), limit of quantification (LOQ), inter- and intra-day precisions and accuracy.

Analytical curves with and without the preconcentration step were constructed in the range of 0.41 to $15.00 \mu \mathrm{g} \mathrm{L}^{-1}$ and 2.50 to $100.00 \mu \mathrm{g} \mathrm{L}^{-1}$ of $\mathrm{Cd}^{2+}$, respectively, with standard solutions of $\mathrm{Cd}^{2+}$ adjusted at $\mathrm{pH} 7.68$ in the presence of $0.023 \mathrm{~mol} \mathrm{~L}^{-1}$ Tris/Tris-HCl buffer. The PF was estimated as the ratio between the angular coefficient of the curve with and without preconcentration step. The CI was determined by the ratio between the sample volume $(10.0 \mathrm{~mL})$ used in the preconcentration step and the $\mathrm{PF}$ value. The $\mathrm{CE}$ was calculated by the ratio between the PF and the preconcentration time (min). The ST was established as the number of analyses performed per hour $\left(h^{-1}\right)$. The LOD and LOQ were estimated according to IUPAC definition, ${ }^{39}$ as $3 \mathrm{SD} / \mathrm{m}$ and $10 \mathrm{SD} / \mathrm{m}$, respectively, where SD is the standard deviation of 10 determinations of the analytical blank and $\mathrm{m}$ is the angular coefficient of the analytical curve with the preconcentration step. The inter- and intra-day precision of the method was obtained as relative standard deviations (RSD) for $n=2$ and $\mathrm{n}=6$, respectively, at three concentration levels $\left(0.50,5.00\right.$ and $\left.15.00 \mu \mathrm{g} \mathrm{L}^{-1}\right)$. The accuracy of the method was evaluated by using recovery/addition tests of spike samples before microwave-assisted acid digestion, as well as by using certified reference material (TORT-2, lobster hepatopancreas). The microwave-assisted acid digestion of the TORT- 2 was performed following the same temperature gradient used for the digestion of the cigarette sample, which is described in the "Sample preparation" sub-section. The TORT- 2 mass used was $50.0 \mathrm{mg}$ (in triplicate), and the solutions from digestion were transferred to a volumetric flask of $200.0 \mathrm{~mL}$.

Interfering study

The $\mathrm{Cd}^{2+}$ online preconcentration using the ASAC adsorbent in FIA-TS-FF-FAAS was also evaluated in the presence of concomitant ions. For this task, solutions containing $5.0 \mu \mathrm{g} \mathrm{L}^{-1} \mathrm{Cd}^{2+}$ and each of the possible interfering ion individually $\left(\mathrm{Ca}^{2+}, \mathrm{Co}^{2+}, \mathrm{Cu}^{2+}, \mathrm{Fe}^{2+}, \mathrm{Pb}^{2+}\right.$ and $\mathrm{Zn}^{2+}$ ) were preconcentrated using the optimal conditions. The ratio $\mathrm{Cd}^{2+}$ :interfering ion investigated were 1:10 and $1: 20(\mathrm{~m} / \mathrm{m})$. In order to evaluate the interference effect, recovery percentages were estimated by comparing the $\mathrm{Cd}^{2+}$ analytical signal obtained in the presence and absence of interfering species. Recoveries of $100 \pm 10 \%$ were considered tolerable to predict the absence of interference.

\section{Sample preparation}

The proposed preconcentration method was applied to cadmium determination in cigarettes, human hair and water samples (lake, tap and mineral). Cigarette and mineral water were purchased in the local supermarket. Lake water was collected from Igapó Lake in the city of Londrina (Paraná, Brazil) and acidified with $\mathrm{HNO}_{3}$ until $\mathrm{pH} 2.00$, while the tap water was collected from the State University of Londrina (Londrina, Paraná, Brazil). The lake and tap waters were filtered in a $0.45 \mu \mathrm{m}$ Nylon (Magna) membrane under vacuum before use. 
The human hair samples (brown and natural without chemicals) were kindly supplied from students of the State University of Londrina, all women with age between 20 to 22 years old. The human hair was cut from the nape of the neck (pieces of 2-3 cm) using sterile stainless-steel scissors. Then, it was sonicated with acetone for $15.0 \mathrm{~min}$ to remove adhered contaminants (fat). Upon this time, it was washed with ultrapure water.

The solid samples were dried at $60^{\circ} \mathrm{C}$ for $24 \mathrm{~h}$. Next, each sample was weighted separately in triplicate (cigarette: $500.0 \mathrm{mg}$ and human hair: $300.0 \mathrm{mg}$ ) into Teflon flask and mixed with $10.0 \mathrm{~mL}$ of concentrated $\mathrm{HNO}_{3}$ and $4.0 \mathrm{~mL}$ of $29.0 \%(\mathrm{v} / \mathrm{v})$ of $\mathrm{H}_{2} \mathrm{O}_{2}$ for the decomposed procedure. The mixture was kept overnight and subsequently subjected to the microwave-assisted acid digestion. For cigarette sample it was used the following temperature gradient with fixed power $(1200 \mathrm{~W})$ : step 1 , heating to $80^{\circ} \mathrm{C}(6.0 \mathrm{~min})$; step 2, plateau at $80^{\circ} \mathrm{C}(5.0 \mathrm{~min})$; step 3, heating to $120^{\circ} \mathrm{C}$ (7.0 min); step 4, plateau at $120^{\circ} \mathrm{C}$ (5.0 min); step 5, heating to $190{ }^{\circ} \mathrm{C}(15.0 \mathrm{~min})$; step 6 , plateau at $190{ }^{\circ} \mathrm{C}$ (15.0 $\mathrm{min}$ ); while the human hair samples were digested using a two-step temperature program (fixed power of $1000 \mathrm{~W}$ ): step 1 , heating to $190{ }^{\circ} \mathrm{C}$ (5.0 min); step 2, plateau at $190{ }^{\circ} \mathrm{C}$ (30.0 min). A $30.0 \mathrm{~min}$ of the cooling time was required to refrigerate the digested samples and also decrease the pressure of the system. After, the digested samples solutions were concentrated near to dryness in a hot plate, to eliminate the excess of $\mathrm{HNO}_{3}$, and then cooled down to room temperature. Next, the digested samples of cigarette and human hair were transferred to a volumetric flask of 25.0 and $50.0 \mathrm{~mL}$, respectively, whose volume was made up with ultrapure water, where the $\mathrm{pH}$ of the all samples was adjusted to 7.68 using $0.023 \mathrm{~mol} \mathrm{~L}^{-1}$ Tris- $\mathrm{HCl}$ buffer previously.

\section{Results and Discussion}

\section{Method optimization by factorial design}

Table 1 shows the factors and their low $(-1)$ and high (1) levels for the 16 experiments carried out in duplicate, while the significance of factors and their interactions in the online FIA-TS-FF-FAAS system are shown in Pareto Chart (Figure 2).

Using absorbance (Abs) as an analytical response, it was observed that most of the factors were statistically significant at a confidence interval of $95.0 \%$ (Figure 2a), being the sample $\mathrm{pH}$ the most significant, followed by the

Table 1. Factors studied, their levels and results $(n=2)$ obtained by a $2^{5-1}$ fractional factorial design

\begin{tabular}{|c|c|c|c|c|c|c|c|}
\hline \multirow{2}{*}{ Factor } & & & & \multicolumn{4}{|c|}{ Level } \\
\hline & & & & \multicolumn{2}{|c|}{ Low $(-1)$} & \multicolumn{2}{|c|}{$\operatorname{High}(1)$} \\
\hline \multicolumn{4}{|c|}{ 1. Sample $\mathrm{pH}^{\mathrm{a}}$} & \multicolumn{2}{|c|}{5.00} & \multicolumn{2}{|c|}{8.00} \\
\hline \multicolumn{4}{|c|}{ 2. Buffer concentration $(\mathrm{BC}) /\left(\mathrm{mol} \mathrm{L}^{-1}\right)$} & \multicolumn{2}{|c|}{0.01} & \multicolumn{2}{|c|}{0.10} \\
\hline \multicolumn{4}{|c|}{ 3. Eluent concentration $(\mathrm{EC}) /\left(\mathrm{mol} \mathrm{L}^{-1}\right)$} & \multicolumn{2}{|c|}{1.0} & \multicolumn{2}{|c|}{2.0} \\
\hline \multicolumn{4}{|c|}{ 4. Adsorbent mass (AM) / mg } & \multicolumn{2}{|c|}{50.0} & \multicolumn{2}{|c|}{100.0} \\
\hline \multicolumn{4}{|c|}{ 5. Preconcentration flow rate $(\mathrm{PFR}) /\left(\mathrm{mL} \mathrm{min}{ }^{-1}\right)$} & \multicolumn{2}{|c|}{2.4} & \multicolumn{2}{|c|}{4.8} \\
\hline Run & $\mathrm{pH}$ & $\mathrm{BC}$ & $\mathrm{EC}$ & $\mathrm{AM}$ & PFR & Absorbance & $\mathrm{ES}^{\mathrm{b}}\left(\times 10^{-3}\right)$ \\
\hline 1 & -1 & -1 & -1 & -1 & 1 & $0.380 ; 0.369$ & $3.040 ; 2.952$ \\
\hline 2 & 1 & -1 & -1 & -1 & -1 & $1.212 ; 1.225$ & $4.848 ; 4.900$ \\
\hline 3 & -1 & 1 & -1 & -1 & -1 & $0.416 ; 0.419$ & $1.664 ; 1.676$ \\
\hline 4 & 1 & 1 & -1 & -1 & 1 & $0.671 ; 0.654$ & $5.368 ; 5.232$ \\
\hline 5 & -1 & -1 & 1 & -1 & -1 & $0.377 ; 0.399$ & $1.508 ; 1.596$ \\
\hline 6 & 1 & -1 & 1 & -1 & 1 & $0.757 ; 0.712$ & $6.056 ; 5.696$ \\
\hline 7 & -1 & 1 & 1 & -1 & 1 & $0.294 ; 0.298$ & $2.352 ; 2.384$ \\
\hline 8 & 1 & 1 & 1 & -1 & -1 & $0.845 ; 0.872$ & $3.380 ; 3.488$ \\
\hline 9 & -1 & -1 & -1 & 1 & -1 & $0.324 ; 0.322$ & $1.296 ; 1.288$ \\
\hline 10 & 1 & -1 & -1 & 1 & 1 & $0.675 ; 0.656$ & $5.400 ; 5.248$ \\
\hline 11 & -1 & 1 & -1 & 1 & 1 & $0.212 ; 0.266$ & $1.696 ; 2.128$ \\
\hline 12 & 1 & 1 & -1 & 1 & -1 & $1.289 ; 1.266$ & $5.156 ; 5.064$ \\
\hline 13 & -1 & -1 & 1 & 1 & 1 & $0.273 ; 0.253$ & $2.184 ; 2.024$ \\
\hline 14 & 1 & -1 & 1 & 1 & -1 & $1.583 ; 1.426$ & $6.332 ; 5.704$ \\
\hline 15 & -1 & 1 & 1 & 1 & -1 & $0.218 ; 0.186$ & $0.872 ; 0.744$ \\
\hline 16 & 1 & 1 & 1 & 1 & 1 & $0.819 ; 0.848$ & $6.552 ; 6.784$ \\
\hline
\end{tabular}

${ }^{a} \mathrm{pH}=5.00$ was buffered with $\mathrm{CH}_{3} \mathrm{COO}^{-} / \mathrm{CH}_{3} \mathrm{COOH}$ buffer and $\mathrm{pH}=8.00$ with Tris/Tris-HCl; ${ }^{\text {b }}$ S: efficiency of sensitivity (absorbance/preconcentration step time (s)). 
(a)

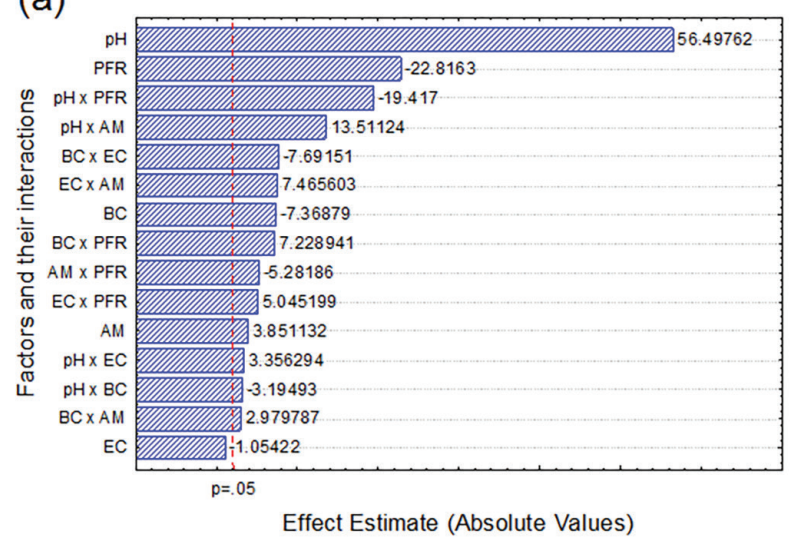

(b)

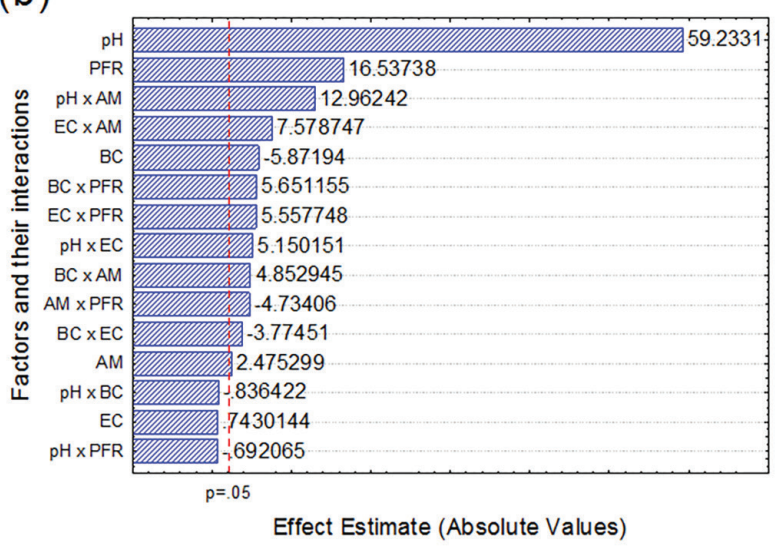

Figure 2. Pareto chart showing the principal effects and their interactions using the absorbance (a) and the efficiency of sensibility (b) as analytical responses. PFR: preconcentration flow rate; AM: adsorbent mass; BC: buffer concentration; EC: eluent concentration.

PFR. This same behavior also was observed when the ES was used as an analytical response (Figure 2b).

The positive effect of sample $\mathrm{pH}$ in both responses (56.50 and 59.23 for Abs and ES, respectively) indicates that increasing $\mathrm{pH}$ values, higher analytical signals can be obtained. In acidic medium, the functional groups such as $\mathrm{O}-\mathrm{H}$ from alcohols and phenols and $\mathrm{C}=\mathrm{O}$ from carboxylic acids and esters are protonated and, consequently, make the interaction with $\mathrm{Cd}^{2+}$ less favorable. On the other hand, under alkaline medium ( $\mathrm{pH}>7.00)$, the ASAC adsorbent surface becomes negatively charged due to the deprotonation of hydroxyl and carbonyl group, thereby favoring the adsorption of $\mathrm{Cd}^{2+}$, which is the predominant species at $\mathrm{pH} \leq 9.00 .^{40} \mathrm{With}$ regard to the $\mathrm{PFR}$, the negative effect $(-22.82)$ indicates, as expected, that the $\mathrm{Cd}^{2+}$ adsorption is more efficient for smaller flow rates. On the other hand, the PFR becomes significant at a higher level $\left(4.8 \mathrm{~mL} \mathrm{~min}^{-1}\right)$, with the positive effect of 16.54 , when the ES is used as the analytical response, thereby indicating that preconcentration time also plays an essential role on the analytical response.
The factor AM was statistically significant on the preconcentration system for both responses, with the positive effect of 3.85 (Abs) and 2.47 (ES) AM.

From the results regarding the influence of $\mathrm{BC}$, it can be observed negative effect for both responses, -7.37 for Abs and -5.87 for ES. These results reveal that higher concentrations of buffer solutions may difficult the mass transfer of $\mathrm{Cd}^{2+}$ towards binding sites of ASAC adsorbent due to the strong interaction between the cadmium and buffer anion, as well as due to lead competition between cadmium ions and cationic ions from buffer solution towards binding sites of adsorbent.

In Figure 2, it may also be observed that the EC was not significant for the two analytical responses, thus indicating the sufficient acid strength under experimental domain to strip out cadmium ions from the adsorbent surface.

In this study, the ES has been chosen as the best response because it considers the preconcentration time, which in turn exert significant influence on sample throughput.

According to aforementioned results, the factors AM, PFR and EC were fixed for further experiments as $100.0 \mathrm{mg}$, $4.8 \mathrm{~mL} \mathrm{~min}^{-1}$ and $2.0 \mathrm{~mol} \mathrm{~L}^{-1}$, respectively. One should note that higher levels of AM and PFR were not investigated to avoid problems associated with leakage in the mini-column by overpressure. Also, although EC has not demonstrated influence within the experimental domain, this factor was set at its highest level to avoid memory effect during several preconcentration/elution cycles.

The final optimization for the sample $\mathrm{pH}$ and $\mathrm{BC}$ was carried out using a Doehlert matrix. The seven experiments required by Doehlert matrix, being the first one performed in triplicate, are shown in Table 2, and the corresponding response surface are displayed in Figure 3. The levels of sample $\mathrm{pH}$ and $\mathrm{BC}$ were varied from 7.00 to 9.00 and from 0.0210 to $0.0410 \mathrm{~mol} \mathrm{~L}^{-1}$, respectively.

Table 2. Doehlert matrix used for optimizing $\mathrm{pH}$ and buffer concentration (BC)

\begin{tabular}{lccc}
\hline \multirow{2}{*}{ Experiment } & \multicolumn{2}{c}{ Factor } & Response \\
\cline { 2 - 3 } & $\mathrm{pH}$ & $\mathrm{BC} /\left(\mathrm{mol} \mathrm{L}^{-1}\right)$ & 0.400 \\
\hline $1^{\mathrm{a}}$ & 8.00 & 0.0210 & 0.347 \\
$1^{\mathrm{a}}$ & 8.00 & 0.0210 & 0.353 \\
$1^{\mathrm{a}}$ & 8.00 & 0.0210 & 0.044 \\
2 & 9.00 & 0.0210 & 0.339 \\
3 & 8.50 & 0.0410 & 0.341 \\
4 & 7.00 & 0.0210 & 0.272 \\
5 & 7.50 & 0.0010 & 0.029 \\
6 & 8.50 & 0.0010 & 0.244 \\
7 & 7.50 & 0.0410 & \\
\hline
\end{tabular}

${ }^{\mathrm{a}}$ Central point. Abs: absorbance (peak height). 


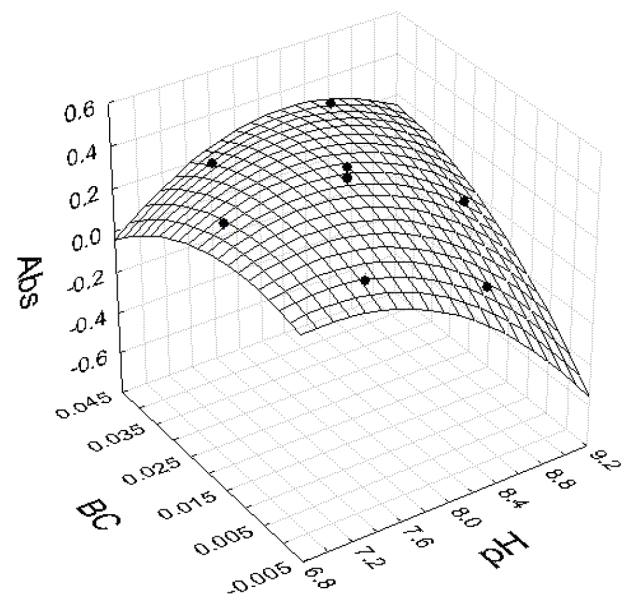

Figure 3. Response surface obtained from Doehlert design for $\mathrm{pH}$ and buffer concentration (BC).

From the Doehlert matrix experiments, a quadratic model was constructed with equation 1 :

Abs $=(-8.558 \pm 7.367)+(2.486 \pm 1.830) \mathrm{pH}-$ $(0.174 \pm 0.114) \mathrm{pH}^{2}-(53.352 \pm 50.847) \mathrm{BC}-$

$(255.312 \pm 213.742) \mathrm{BC}^{2}+(8.450 \pm 6.244) \mathrm{pH} \times \mathrm{BC}$

From ANOVA, the value of $F_{\text {cal }}\left(\mathrm{MS}_{\text {lack of fit }} / \mathrm{MS}_{\text {pure error }}\right)$ was found to be 4.39, which is lower than the value of $F_{\text {tab }}$ (18.51), thereby indicating that the quadratic model does not present lack of fit, with a value of $\mathrm{R}^{2}$ (determination coefficient) of 0.964 and $\mathrm{R}^{2}$ adjusted of 0.904 . Thus, using the derivative of equation 1 , the critical values for $\mathrm{pH}$ and $\mathrm{BC}$ were found to be 7.68 and $0.023 \mathrm{~mol} \mathrm{~L}^{-1}$, respectively. Thus, the optimized values for $\mathrm{pH}, \mathrm{BC}, \mathrm{EC}, \mathrm{AM}$ and PFR were 7.68, $0.023 \mathrm{~mol} \mathrm{~L}^{-1}, 2.0 \mathrm{~mol} \mathrm{~L}^{-1}, 100.0 \mathrm{mg}$ and $4.8 \mathrm{~mL} \mathrm{~min}^{-1}$, respectively.

\section{Analytical performance of the preconcentration method}

Under optimized conditions, the $\mathrm{Cd}^{2+}$ online preconcentration in FIA-TS-FF-AAS system presented analytical curve in the range of 0.41 to $15.00 \mu \mathrm{g} \mathrm{L}^{-1}$ yielding the linear equation: $\mathrm{Abs}=7.19 \times 10^{-2}\left[\mathrm{Cd}^{2+}(\mu \mathrm{g} \mathrm{L}-1)\right]+0.02867$ with the linear correlation coefficient (r) equal to 0.998 . For the analytical curve without the preconcentration, the linear range was 2.5 to $100.00 \mu \mathrm{g} \mathrm{L}^{-1}$ of $\mathrm{Cd}^{2+}$ with the linear equation: $\mathrm{Abs}=6.72 \times 10^{-3}\left[\mathrm{Cd}^{2+}\left(\mu \mathrm{g} \mathrm{L}^{-1}\right)\right]+0.04728$ and $\mathrm{r}=0.990$. The PF, CE, CI and ST values estimated were $10.7,5.14 \mathrm{~min}^{-1}, 0.93 \mathrm{~mL}$ and $26 \mathrm{~h}^{-1}$, respectively. The LOD and LOQ calculated were found to be 0.12 and $0.41 \mu \mathrm{g} \mathrm{L}^{-1}$, respectively.

The relative standard deviation results for inter-day precision $(\mathrm{n}=2)$ were $0.48,0.90$ and $2.30 \%$ for the $\mathrm{Cd}^{2+}$ concentrations of $0.50,5.00$ and $15.00 \mu \mathrm{g} \mathrm{L}{ }^{-1}$, respectively, while intra-day precision $\mathrm{RSD}$ values $(\mathrm{n}=6)$ were 0.30 $\left(0.50 \mu \mathrm{g} \mathrm{L}^{-1} \mathrm{Cd}^{2+}\right), 0.44\left(5.00 \mu \mathrm{g} \mathrm{L}^{-1} \mathrm{Cd}^{2+}\right)$ and $2.48 \%$ $\left(15.00 \mu \mathrm{g} \mathrm{L}^{-1} \mathrm{Cd}^{2+}\right)$. The RSD values found in this study were lower that $5.00 \%$ and considered as satisfactory.

The proposed preconcentration method regarding the analytical performance was compared to some previously published methods for the determination of $\mathrm{Cd}^{2+}$ by TS-FF-AAS (Table 3).

As can be seen in Table 3, the proposed method provided better or similar analytical performance regarding LOQ and linear range compared to previously published methods. Moreover, as the highlight of the proposed method, it can be mentioned the absence of toxic organic solvent in the elution step and the very low cost for producing the adsorbent.

Table 3. Comparison of the analytical performance of the proposed method with previously published methods for the Cd ${ }^{2+}$ determination by TS-FF-AAS

\begin{tabular}{|c|c|c|c|c|c|c|c|c|c|c|}
\hline $\begin{array}{l}\text { Detection } \\
\text { mode }\end{array}$ & $\begin{array}{c}\text { Preconcentration } \\
\text { modality }\end{array}$ & Adsorbent & $\begin{array}{l}\text { Linear } \\
\text { range / } \\
\left(\mu \mathrm{g} \mathrm{L}^{-1}\right)\end{array}$ & $\begin{array}{l}\mathrm{LOD} / \\
\left(\mu \mathrm{g} \mathrm{L}{ }^{-1}\right)\end{array}$ & $\begin{array}{l}\mathrm{LOQ} / \\
\left(\mu \mathrm{g} \mathrm{L}{ }^{-1}\right)\end{array}$ & $\mathrm{PF}$ & $\mathrm{PV} / \mathrm{mL}$ & $\mathrm{ST} / \mathrm{h}^{-1}$ & Sample & Reference \\
\hline TS-FF-AAS & online SPE & RACNTs & $0.80-30.00$ & 0.24 & 0.80 & 10.8 & 2.0 & 8.6 & blood serum & 41 \\
\hline TS-FF-AAS & online SPE & fullerene & $0.50-5.00$ & 0.10 & 0.40 & 11.0 & 1.5 & 24.0 & $\begin{array}{l}\text { mineral, tap and } \\
\text { drinking waters }\end{array}$ & 42 \\
\hline TS-FF-AAS & online SPE & $\begin{array}{l}\text { polyurethane } \\
\text { foam }\end{array}$ & $0.40-15.00$ & 0.12 & 0.40 & 216.0 & 2.0 & 16.0 & $\begin{array}{l}\text { mineral and lake waters, } \\
\text { physiological serum and } \\
\text { intravenous solutions }\end{array}$ & 43 \\
\hline TS-FF-AAS & online SPE & $\begin{array}{l}\text { activated } \\
\text { carbon } \\
\text { adsorbent } \\
\text { from ASAC }\end{array}$ & $0.41-15.00$ & 0.12 & 0.41 & 10.9 & 10.0 & 15.0 & $\begin{array}{l}\text { mineral, tap and } \\
\text { lake waters and } \\
\text { cigarette and hair }\end{array}$ & this work \\
\hline
\end{tabular}

LOD: limit of detection; LOQ: limit of quantification; PF: preconcentration factor; PV: preconcentration volume; ST: sample throughput; TS-FF-AAS: thermospray flame furnace atomic absorption spectrometry; SPE: solid-phase extraction; RACNT: raw carbon nanotubes; ASAC: avocado seed activated carbon; NI: not informed. 
Interfering study

Figure 4 shows the effect of possible interfering ions $\left(\mathrm{Ca}^{2+}, \mathrm{Co}^{2+}, \mathrm{Cu}^{2+}, \mathrm{Fe}^{2+}, \mathrm{Pb}^{2+}\right.$, and $\left.\mathrm{Zn}^{2+}\right)$ on the $\mathrm{Cd}^{2+}$ absorbance obtained from online preconcentration system.

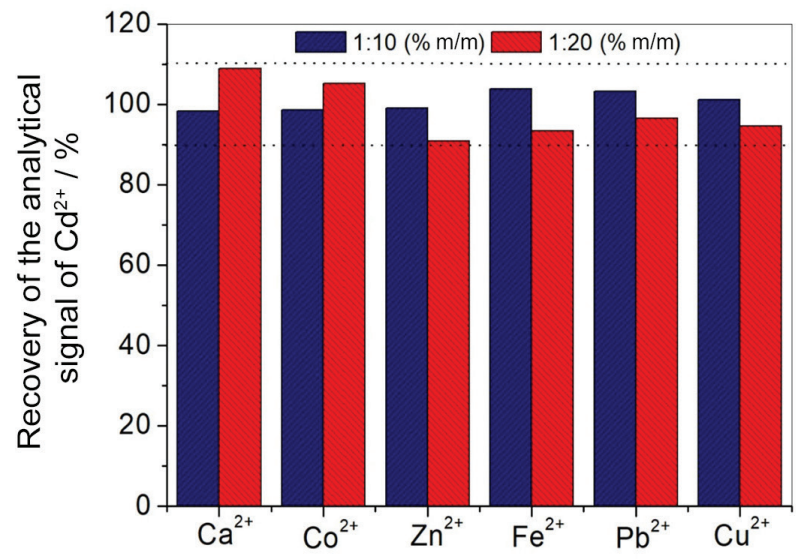

Figure 4. Effect of interfering ions on the recovery of $5.0 \mu \mathrm{g} \mathrm{L}^{-1}$ of $\mathrm{Cd}^{2+}$ in FIA-TS-FF-AAS system.

As can be seen in Figure 4, the proposed method is tolerable to the high concentration of concomitant ions (1:20\% $\mathrm{m} / \mathrm{m}, \mathrm{Cd}^{2+}:$ interfering ion), whose result can be explained to the high surface area of adsorbent and binding sites available.

\section{Application}

In order to verify the applicability of the proposed method, samples of cigarette, human hair and different water samples (lake, tap and mineral) were subjected to analysis. Table 4 shows the $\mathrm{Cd}^{2+}$ concentration found in real samples.

As observed in Table 4, except for the tap and mineral water, cadmium was quantified in the samples. The accuracy of such analysis was attested using satisfactory recovery percentage (97.3-107.1\%), which confirms the interference-free determination. The cadmium concentration achieved in water samples was lower than the established by governmental organizations of Brazil as ANVISA (3.0 $\mu \mathrm{g} \mathrm{L}^{-1}$ for drinking water $)^{7}$ and CONAMA (10.0 $\mu \mathrm{g} \mathrm{L}^{-1}$ for freshwater). ${ }^{9}$

The accuracy of the proposed method was also checked using analysis of the certified reference material TORT-2. The concentration value of $\mathrm{Cd}^{2+}$ found by the present method $\left(26.44 \pm 0.02 \mathrm{mg} \mathrm{kg}^{-1}\right)$ was not statistically different to the value of the certified value in TORT-2 $\left(26.70 \pm 0.60 \mathrm{mg} \mathrm{kg}^{-1}\right)$ according to $t$-test at $95.0 \%$ confidence level, which confirms the accuracy of the proposed method.
Table 4. $\mathrm{Cd}^{2+}$ ions determined in real samples using ASAC adsorbent in FIA-TS-FF-AAS system (numbers are mean concentration values \pm standard deviation $(\mathrm{SD})(\mathrm{n}=3))$

\begin{tabular}{lccc}
\hline Sample & $\begin{array}{c}\text { Amount added } \\
\mathrm{Cd}^{2+} /\left(\mu \mathrm{gg}^{-1}\right)\end{array}$ & $\begin{array}{c}\text { Amount found } \\
\mathrm{Cd}^{2+} \pm \mathrm{SD} / \\
\left(\mu \mathrm{gg}^{-1}\right)\end{array}$ & Recovery / \% \\
\hline Cigarette & - & $62.84 \pm 11.28$ & - \\
Human hair & 64.63 & $123.98 \pm 8.08$ & 97.3 \\
\hline \multirow{3}{*}{ Sample } & - & $69.61 \pm 2.38$ & - \\
& $\mathrm{Amount} \mathrm{added}^{2+} /(\mu \mathrm{g} \mathrm{L}-1)$ & $\begin{array}{c}\mathrm{Amount} \text { found } \\
\mathrm{Cd}^{2+} \pm \mathrm{SD} / \\
(\mu \mathrm{gg} \mathrm{L})\end{array}$ & Recovery / \% \\
\hline Lake Igapó & - & $0.65 \pm 0.01$ & - \\
water & 3.00 & $3.91 \pm 0.02$ & 107.1 \\
Tap water & - & $\mathrm{ND}$ & - \\
& 3.00 & $3.09 \pm 0.02$ & 103.1 \\
Mineral water & - & $\mathrm{ND}$ & - \\
& 3.00 & $3.07 \pm 0.02$ & 102.2 \\
\hline
\end{tabular}

ND: below limit of quantification.

Based on the concentrations obtained for the solid samples, the LOD and LOQ were calculated in mass/mass basis, whose values correspond to 2.4 and $8.2 \mu \mathrm{g} \mathrm{kg}^{-1}$ for cigarette; 4.0 and $13.7 \mu \mathrm{g} \mathrm{kg}^{-1}$ for hair; and 24.0 and $82.0 \mu \mathrm{g} \mathrm{kg}^{-1}$ for CRM (TORT-2), respectively.

\section{Conclusions}

In this paper, the ASAC was used for the first time as an adsorbent for the $\mathrm{Cd}^{2+}$ online determination in the FIA-TS-FAAS system. The proposed method provided better or similar analytical parameters when compared to previously published methods for cadmium determination by TS-FF-AAS associated with preconcentration. Some important analytical features can be highlighted including satisfactory preconcentration factor, with low sample consumption and low detection limit. Also, the proposed method is prone to be applied to cadmium determination in different kind of samples without matrix interference. The use of activated carbon from ASAC may be considered as an effective alternative to be used in preconcentration systems for the determination of $\mathrm{Cd}^{2+}$ in low concentration levels, presenting low production costs and low environmental impact.

\section{Acknowledgments}

The authors acknowledge the financial support and fellowships of Coordenação de Aperfeiçoamento de Nível 
Superior (CAPES) (Project Pró-Forenses 3353/2014 grant No. 23038.007082/2014-03), Conselho Nacional de Desenvolvimento Científico e Tecnológico (CNPq) (grant No. 481669/2013-2, 305552/2013-9, 307432/2017-3), Fundação Araucária do Paraná (163/2014), SETI do Paraná, and Instituto Nacional de Ciência e Tecnologia de Bioanalítica (INCT) (FAPESP grant No. 2014/50867-3 and CNPq grant No. 465389/2014-7).

\section{References}

1. Mishra, S. P.; Curr. Sci. 2014, 107, 601.

2. Deng, Z. L.; Liang, M. N.; Li, H. H.; Zhu, Z. J.; IOP Conf. Ser.: Earth Environ. Sci. 2016, 39, DOI: 10.1088/17551315/39/1/012065.

3. International Agency for Research on Cancer (IARC); Scand. J. Work, Environ. Health 1993, 19, 360.

4. Usman, A.; Sallam, A.; Zhang, M.; Vithanage, M.; Ahmad, M.; Al-Farraj, A.; Ok, Y. S.; Abduljabbar, A.; Al-Wabel, M.; Water, Air, Soil Pollut. 2016, 227, 449.

5. Milačič, R.; Zuliani, T.; Vidmar, J.; Oprčkal, P.; Ščančar, J.; Sci. Total Environ. 2017, 605-606, 894.

6. https://www.epa.gov/sites/production/files/2016-06/documents/ npwdr_complete_table.pdf, accessed in August 2018.

7. http://www4.anvisa.gov.br/base/visadoc/CP/CP\%5B8998-10\%5D.PDF, accessed in August 2018.

8. http://apps.who.int/iris/bitstream/handle/10665/254637/ 9789241549950-eng.pdf;jsessionid=7C8A6ECE3B8ED1181 5030ACD748091E4? sequence=1, accessed in August 2018.

9. http://www.mma.gov.br/port/conama/res/res05/res35705.pdf, accessed in August 2018.

10. Tarley, C. R. T.; Figueiredo, E. C.; Matos, G. D.; Anal. Sci. 2005, 21, 1337.

11. Diniz, K. M.; Segatelli, M. G.; Tarley, C. R. T.; React. Funct. Polym. 2013, 73, 838.

12. Nascentes, C. C.; Kamogawa, M. T.; Fernandes, K. G.; Arruda, M. A. Z.; Nogueira, N. R.; Nóbrega, J. A.; Spectrochim. Acta, Part B 2005, 60, 749 .

13. Tarley, C. R. T.; Corazza, M. Z.; Oliveira, F. M.; Somera, B. F.; Nascentes, C. C.; Segatelli, M. G.; Microchem. J. 2017, 131, 57.

14. Corazza, M. Z.; Tarley, C. R. T.; Microchem. J. 2016, 127, 145.

15. Zeng, C.; Hu, Y.; Luo, J.; Microchim. Acta 2012, 177, 53.

16. Beal, A.; Almeida, F. G.; Moreira, C. A. B.; Santos, I. M.; Curti, S. M. M.; Martins, L. D.; Tarley, C. R. T.; Anal. Methods 2018, 10,3745 .

17. Garcia, S.; Gerondi, F.; Paixão, T. R. L. C.; Arruda, M. A. Z.; Gaubeur, I.; J. Braz. Chem. Soc. 2015, 26, 490.

18. Jia, W. P.; Hu, Y.; Li, F.; Han, D. M.; At. Spectrosc. 2015, 36, 96.
19. Lago, A. C.; Marchioni, C.; Mendes, T. V.; Wisniewski, C.; Fadini, P. S.; Luccas, P. O.; Appl. Spectrosc. 2016, 70, 1842.

20. Tarley, C. R. T.; Diniz, K. M.; Suquila, F. A. C.; Segatelli, M. G.; RSC Adv. 2017, 7, 19296.

21. Karnib, M.; Kabbani, A.; Holail, H.; Olam. Z.; Energy Procedia 2014, 50, 113.

22. Shahata, M. M.; Arabian J. Chem. 2016, 9, 755.

23. Mahmoud, M. E.; Osman, M. M.; Hafez, O. F.; Hegazi, A. H.; Elmelegy, E.; Desalination 2010, 251, 123.

24. Xu, Y.-J.; Arrigo, R.; Liu, X.; Su, D. S.; New Carbon Mater. 2011, 26, 57.

25. Mahmood, T.; Saddique, M. T.; Naeem, A.; Mustafa, S.; Zeb, N.; Shah, K. H.; Waseem, M.; Chem. Eng. J. 2011, 171, 935.

26. El-Kafrawy, A. F.; El-Saeed, S. M.; Farag, R. K.; El-Saied, H. Al-A.; Abdel-Raouf, M. El-S.; Egypt. J. Pet. 2017, 26, 23.

27. Lin, S. H.; Shu, L. L.; Horng, G. L.; J. Hazard. Mater. 2000 , $76,139$.

28. Feist, B.; Mikula, B.; Food Chem. 2014, 147, 302.

29. Ramos, P. H.; Guerreiro, M. C.; Resende, E. C.; Gonçalves, M.; Quim. Nova 2009, 32, 1139.

30. Lloyd-Jones, P. J.; Rangel-Mendez, J. R.; Streat, M.; Symp. Ser. 2001, 847.

31. Yin, C. Y.; Aroua, M. K.; Daud, W. M. A. W.; Sep. Purif. Technol. 2007, 52, 403.

32. Zhang, L.; Li, Z.; Du, X.; Li, R.; Chang, X.; Spectrochim. Acta, Part A 2012, 86, 443.

33. Leite, A. J. B.; Carmalin, S. A.; Thue, P. S.; Reis, G. S.; Dias, S. L. P.; Lima, E. C.; Vaghetti, J. C. P.; Pavan, F. A.; Alencar, W. S.; Desalin. Water Treat. 2017, 71, 168.

34. Tajar, A. F.; Kaghazchi, T.; Soleimani, M.; J. Hazard. Mater. 2009, 165, 1159.

35. Khan, M. N.; Wahab, M. F.; J. Hazard. Mater. 2007, 141, 237.

36. Amuda, O. S.; Giwa, A. A.; Bello, I. A.; Biochem. Eng. J. 2007, $36,174$.

37. Nanicuacua, D. M.; Segatelli, M. G.; Corazza, M. Z.; Tarley, C. R. T.; Anal. Methods 2016, 8, 2820.

38. STATISTICA 7.0; StatSoft, Tulsa, USA, 1984-2004.

39. International Union of Pure Applied Chemistry (IUPAC); Pure Appl. Chem. 1995, 67, 1699.

40. Anielak, A. M.; Schmidt, R.; Pol. J. Environ. Stud. 2011, 20, 15.

41. Barbosa, A. F.; Barbosa, V. M. P.; Bettini, J.; Luccas, P. O.; Figueiredo, E. C.; Talanta 2015, 131, 213.

42. Pereira, M. G.; Pereira-Filho, E. R.; Arruda, M. A. Z.; Spectrochim. Acta, Part B 2004, 59, 515.

43. Tarley, C. R. T.; Arruda, M. A. Z.; Anal. Sci. 2004, 20, 961.

Submitted: December 15, 2018

Published online: June 7, 2019 